\title{
Idiopathic Nonobstructive Colo-colonic Intussusception: A Rare Clinical Presentation
} \section{İdiyopatik Nonobstrüktif Kolo-kolonik İntussusepsiyon: Nadir Bir Klinik Tablo}

\author{
(1) Fatma Ayça Gültekin1, (1) Ramazan Kozan1, (1) Yücel Üstündağ2 \\ 1Zonguldak Bülent Ecevit University Faculty of Medicine, Department of General Surgery, Zonguldak, Turkey \\ 2Zonguldak Bülent Ecevit University Faculty of Medicine, Department of Internal Diseases, Division of Gastroenterology, Zonguldak, Turkey
}

\begin{abstract}
IIIIIIII| ABSTRACT
Adult intussusception is a rare clinical condition. There is generally an etiological factor, mainly malignancy. However, the number of idiopathic cases is very low. Patients may present with obstruction or acute abdomen, but the symptoms and signs may also be nonspecific. The diagnostic process is more difficult in patients with non-specific clinical presentation. In this article, the diagnosis and treatment options of an adult idiopathic colo-colonic intussusception are discussed.
\end{abstract}

Keywords: Intussusception, adult, idiopathic, colonic diseases, laparoscopy

\section{||||||||||| Öz}

İntussusepsiyon erişkinlerde nadir görülen bir durumdur. Başta malignite olmak üzere etiyolojik faktör sıklıkla tespit edilebilmektedir. Buna karşın idiyopatik olgu sayısı oldukça azdır. Klinik tablo, intestinal obstrüksiyon veya akut karının yanı sıra spesifik olmayan semptom ve bulgular şeklinde de ortaya çıkabilmektedir. Bu hastalarda tanısal süreç daha güçtür. Etkin preoperatif değerlendirme seçilecek cerrahi tedavi şekli ve genişliğini belirlemesi açısından önem taşır. Bu yazıda yetişkin bir idiyopatik kolo-kolonik intussusepsiyon olgusu eşliğinde tanı ve tedavi seçenekleri tartışılmıştır.

Anahtar Kelimeler: İntussusepsiyon, erişkin, idiyopatik, kolonik hastalıklar, laparoskopi

\section{Introduction}

Intussusception is most common in infants and children, but rare in adults, representing $5 \%$ of all bowel intussusceptions and $1 \%$ of all bowel obstructions. ${ }^{1,2,3,4}$ The large bowel is the most common site for adult intussusception, and $80 \%$ of cases are colo-colonic intussusception. ${ }^{5} \mathrm{~A}$ causal lesion is identified in $90 \%$ of adult intussusceptions and $44 \%$ of these lesions are malignant. ${ }^{6}$ However, there are few cases of adult colo-colonic intussusception without any identifiable lesion in the literature. In this article, we report a case of adult colocolonic intussusception without any pathologic underlying cause who was treated by laparoscopic resection.

\section{Case Report}

A 41-year-old male patient was admitted to emergency department with a complaint of abdominal colic pain predominantly in the left flank for 10 days. Two day before the admission, the patient reported worsening abdominal pain, nausea and vomiting. His bowel movement was normal. He had no comorbid disease, previous abdominal surgery or family history of colorectal cancer. Physical examination revealed painful abdominal distention without signs of peritoneal irritation. Bowel sounds were present. Initial laboratory values were within normal limits. Abdominal $\mathrm{X}$-rays were taken and did not show any signs of obstruction or perforation.

Address for Correspondence/Yazışma Adresi: Ramazan Kozan MD,

Zonguldak Bülent Ecevit University Faculty of Medicine, Department of General Surgery, Zonguldak, Turkey

Phone: +90 5327631697 E-mail: dr.kozan@hotmail.com ORCID ID: orcid.org/0000-0002-3835-8759

Received/Geliş Tarihi: 23.09.2018 Accepted/Kabul Tarihi: 28.10.2018

${ }^{\circ}$ Copyright 2019 by Turkish Society of Colon and Rectal Surgery

Turkish Journal of Colorectal Disease published by Galenos Publishing House. 
Abdominal and pelvic computed tomography (CT) demonstrated thickening of the sigmoid colon wall and mild distension of the ascending and transverse colon. Magnetic resonance imaging (MRI) was performed in accordance with the recommendations of radiology department on the basis of suspicion of intussusception in CT and thickening of the wall. Abdominal and pelvic MRI revealed "bowel within bowel" colo-colonic intussusception at the level of descending colon and sigmoid colon (Figure 1). The length of the affected colon segment was about $10 \mathrm{~cm}$. In the absence of signs suggestive of acute intestinal obstruction, the patient was hospitalized for further investigation. On the second day of hospitalization, colonoscopy was performed in order to exclude malignancy. In the colonoscopic examination, congested colonic mucosa completely filled the colon lumen without evidence of malignancy, but permitted the advance of the colonoscopy (Figure 2). According to the findings, the patient was prepared for laparoscopic sigmoid resection with bowel cleansing. Intraoperatively, a round mass-like appearance was observed in the sigmoid colon as a result

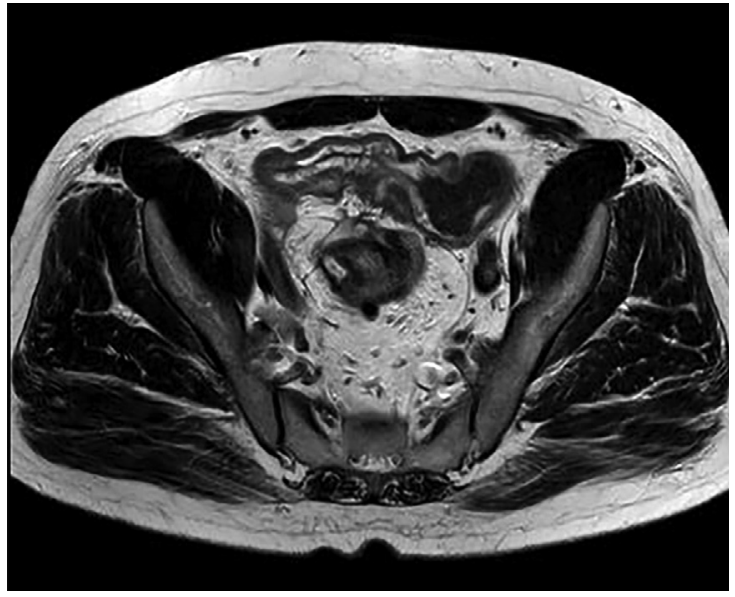

Figure 1. Magnetic resonance appearance of colo-colonic intussusception at the level of descending colon and sigmoid colon

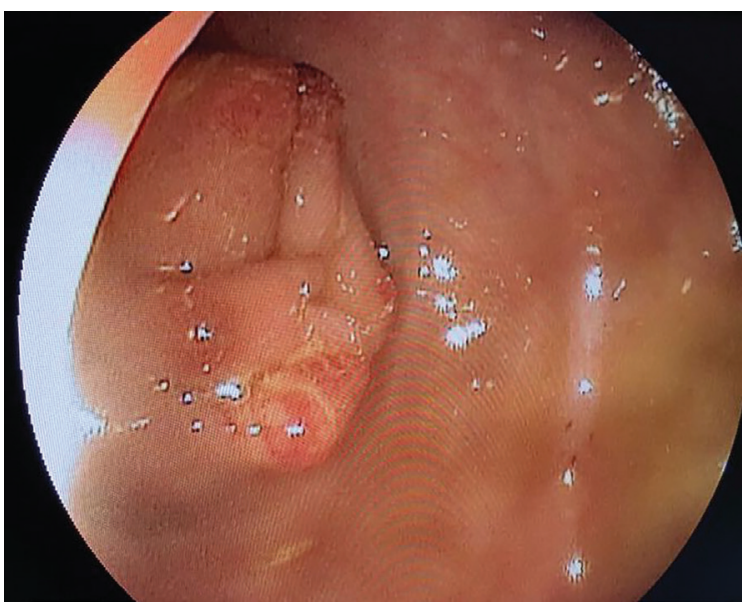

Figure 2. Colonoscopic view of colo-colonic intussusception of an invagination of the descending colon into the sigmoid colon (Figure 3). Loose adhesions were also observed between the affected bowel segment and pelvic walls (Figure 4). No other abnormality was found. Laparoscopic resection of descending colon and primary anastomosis were performed. Gross examination of the resected specimen revealed a $15 \mathrm{~cm}$ colo-colonic intussusception (Figure 5). Histological examination revealed non-specific mucosal inflammation and fibrotic thickening at serosal surfaces

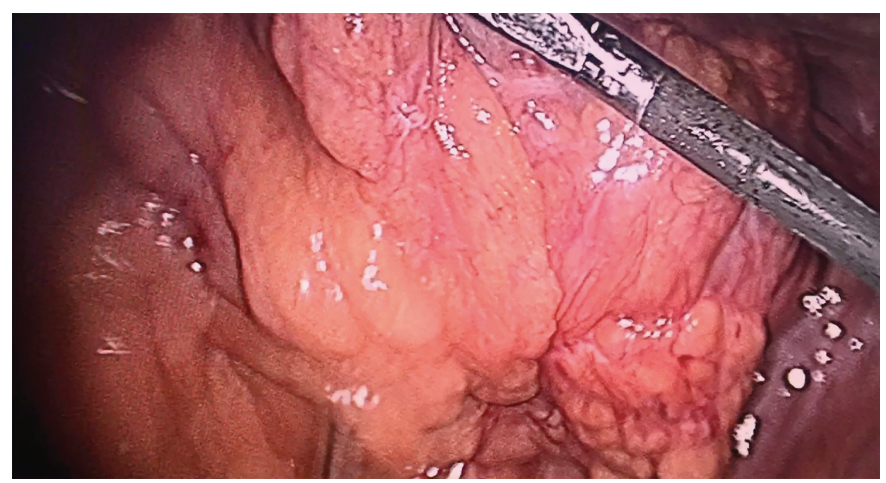

Figure 3. A round mass like appearance in the sigmoid colon (arrow) due to colo-colonic intussusception

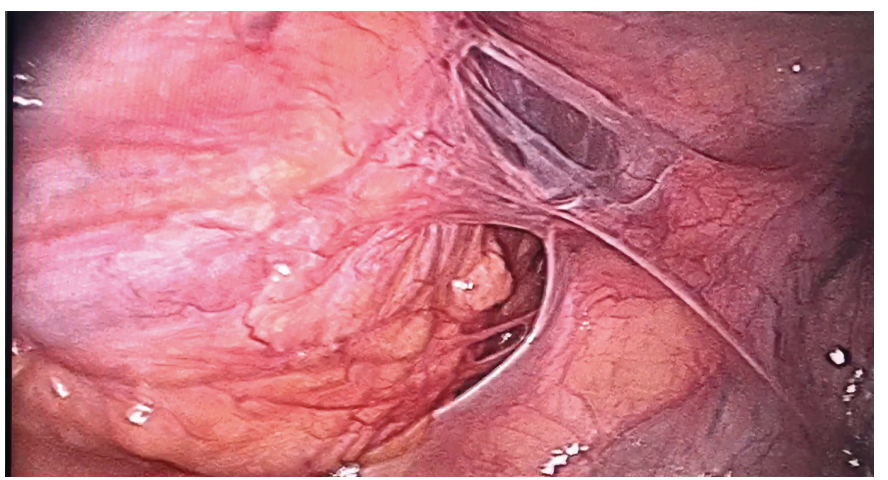

Figure 4. Loose adhesions between the affected bowel segment and pelvic walls

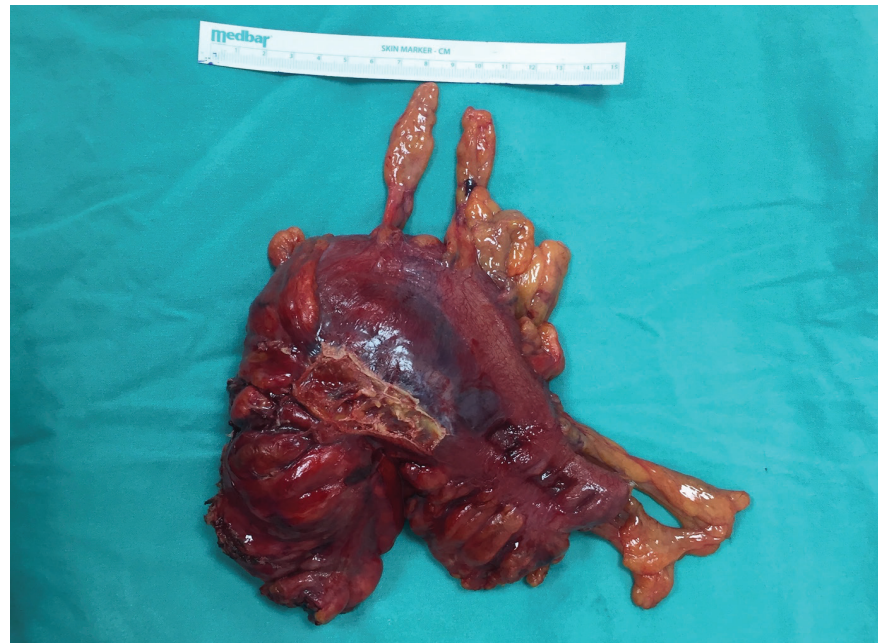

Figure 5. A macroscopic view of the resected specimen 
of the colon segments. No neoplastic or benign lesion was identified. The postoperative period was uneventful and the patient was discharged on the fifth postoperative day. Written informed consent was obtained from the patient for the use of medical data.

\section{Discussion}

Adult intussusception is a rare clinic entity. The signs and symptoms of adult colo-colonic intussusception are nonspecific, and most patients present with chronic or intermittent abdominal pain, partial intestinal obstruction and gastrointestinal bleeding. ${ }^{7}$ In the literature, $75 \%$ of patients presented with obstruction symptoms, 5\% with acute abdomen, and one third of patients had a palpable abdominal mass. In adult patients, an underlying cause is found in $75-90 \%$ of patients, and malignancy is the most common etiology. Adenocarcinoma was particularly common in adult colo-colonic intussusception. ${ }^{8}$

An accurate preoperative diagnosis of adult colo-colonic intussusception is relatively difficult. There is no specific laboratory finding for adult intussusception. Due to being cost effective, ultrasonography (US) is considered a first-level diagnostic technique. The characteristic ultrasonographic findings of intussusception include the "target" or "doughnut" signs in the transverse view and the "pseudo-kidney" sign or "hay-fork" sign in the longitudinal view. ${ }^{9,10}$ However, accuracy of US depends on status of patient body (obese patient etc.) and experience of radiologist. CT is the most valuable imaging technique to confirm a preoperative diagnosis of intussusception. The diagnostic accuracy of CT reported for intussusception is 58-100\%. ${ }^{6}$ CT can also demonstrate any mass associated with intussusception and may help assess the location and character of the mass and its association with surrounding tissues. CT can provide diagnostic findings of intussusception including an inhomogeneous "target" or "sausage" shaped soft tissue mass with a layering effect and/ or an apparent mass lesion. ${ }^{11,12}$ Endoscopic investigations such as colonoscopy and sigmoidoscopy can help identify both intussusception and the underlying causes (leading point) of intussusception and collect a histology sample. ${ }^{6}$ However, in case of intestinal obstruction, endoscopy is not advisable due to the high risk of perforation. As the patient in our case did not show typical symptoms associated with intestinal obstruction, we performed colonoscopy.

The treatment of choice for adult intussusception is surgical resection of the affected bowel segment. The extent of resection depends on the underlying cause of intussusception, and malignant lesions require oncologic resection. ${ }^{6}$ In patients with right sided intussusception (ileo- colonic, ileo-cecal and colo-colonic), construction with primary anastomosis is recommended, whereas Hartman procedure is more appropriate surgical option for leftsided or rectosigmoid intussusceptions, especially in the emergency setting. ${ }^{7}$ In contrast to most pediatric patients, preoperative reduction of intussusception is not feasible for adult patients, and carries increased risk of perforation, tumor seeding (particularly intussusception associated with malignant lesions) and anastomotic complications. However, if preoperative diagnosis of lesion is benign and the bowel wall looks viable and healthy, reduction may be performed in order to limit extent of bowel resection.

Successful laparoscopic resections in adult intussusception cases have been reported in the literature..$^{13,14,15}$ Laparoscopy can be used for both diagnostic and operative purposes. Once the diagnosis of intussusception and underlying disease is confirmed laparoscopically, the surgeon can perform laparoscopic resection. However, the characteristics of intussusception (location and extent), underlying cause and the expertise of the surgeon affects the outcome of laparoscopic surgery. In this case, preoperative diagnosis of intussusception was performed by CT, MRI and colonoscopy, and laparoscopic resection was performed successfully.

\section{Conclusion}

In conclusion, idiopathic colo-colonic intussusception without intestinal obstruction is a rare clinical phenomenon. Non-specific clinical presentation makes the preoperative diagnosis of intussusception difficult. However, CT can help to establish preoperative diagnosis. Resection of the affected bowel segment is recommended and choice of surgical technique (laparoscopic or open) should be made based on characteristics of intussusception and the experience of the surgeon.

\section{Ethics}

Informed Consent: Written informed consent was obtained from patient in this case.

Peer-review: External and internal peer-reviewed.

\section{Authorship Contributions}

Surgical and Medical Practices: F.A.G., R.K., Y.U., Concept: F.A.G., Y.U., Design: F.A.G., R.K., Data Collection or Processing: F.A.G., Y.U., Analysis or Interpretation: F.A.G., R.K., Literature Search: F.A.G., R.K., Writing: F.A.G., R.K.

Conflict of Interest: No conflict of interest was declared by the authors.

Financial Disclosure: The authors declared that this study received no financial support. 


\section{References}

1. Rutherford CL, Alkhaffaf B, Massa E, Turner P. Colo-colic intussusception secondary to lipomatous polyp in an adult. BMJ Case Rep 2013;2013: bcr2012008037.

2. El-Sergany A, Darwish A, Mehta P, Mahmoud A. Community teaching hospital surgical experience with adult intussusception: Study of nine cases and literature review. Int J Surg Case Rep 2015;12:26-30.

3. Honjo $\mathrm{H}$, Mike M, Kusanagi $\mathrm{H}$, Kano N. Adult intussusception: a retrospective review. World J Surg 2015;39:134-138.

4. Lianos G, Xeropotamos N, Bali C, Baltogiannis G, Ignatiadou E. Adult bowel intussusception: presentation, location, etiology, diagnosis and treatment. G Chir 2013;34:280-283.

5. Eisen LK, Cunningham JD, Aufses AH Jr. Intussusception in adults: institutional review. J Am Coll Surg 1999;188:390-395.

6. Marinis A, Yiallourou A, Samanides L, Dafnios N, Anastasopoulos $G$, Vassiliou I, et al. Intussusception of the bowel in adults: a review. World J Gastroenterol 2009;15:407-411.

7. Azar T, Berger DL. Adult intussusception. Ann Surg 1997;226:134-138.

8. Begos DG, Sandor A, Modlin IM. The diagnosis and management of adult intussusception. Am J Surg 1997;173:88-94.
9. Boyle MJ, Arkell LJ, Williams JT. Ultrasonic diagnosis of adult intussusception. Am J Gastroenterol 1993;88:617-618.

10. Weissberg DL, Scheible W, Leopold GR. Ultrasonographic appearance of adult intussusception. Radiology 1977;124:791-792.

11. Gayer G, Apter S, Hofmann C, Nass S, Amitai M, Zissin R, et al. Intussusception in adults: CT diagnosis. Clin Radiol 1998;53:53-57.

12. Gayer G, Zissin R, Apter S, Papa M, Hertz M. Pictorial review: adult intussusception-a CT diagnosis. Br J Radiol 2002;75:185-190.

13. Ishibashi Y, Yamamoto S, Yamada Y, Fujita S, Akasu T, Moriya Y. Laparoscopic resection for malignant lymphoma of the ileum causing ileocecal intussusception. Surg Laparosc Endosc Percutan Tech 2007;17:444-446.

14. Akatsu T, Niihara M, Kojima K, Kitajima M, Kitagawa Y, Murai S. Adult colonic intussusception caused by cecum adenoma: successful treatment by emergency laparoscopy: report of a case. Surg Today 2007;37:694-697.

15. Palanivelu C, Rangarajan M, Senthilkumar R, Madankumar MV. Minimal access surgery for adult intussusception with subacute intestinal obstruction: a single center's decade-long experience. Surg Laparosc Endosc Percutan Tech 2007;17:487-491. 